\title{
Penerapan Model Pembelajaran CIRC untuk Meningkatkan Keterampilan Menulis Surat Undangan di Sekolah Dasar
}

\author{
Susilailiy Rahmawati \\ Universitas Sebelas Maret \\ susilailiyrahmawati7@gmail.com
}

\section{Article History}

received 30/4/2021

revised 30/5/2021

accepted 30/6/2021

\begin{abstract}
The research is motivated by the proces and the result of learning of the content of Indonesian language of the fifth grade students that are still low in one of the SD Negeri 1 Lundong. The purpose of this research is to improve the skills of writing invitation letters in the fifth grade students of SD Negeri 1 Lundong through The CIRC Model. This research was classroom action research, it conducted in three cycles. Each cycle consisted of four phases, namely: planning, implementation, observation, and reflection. The subjects of this research were the fifth grade students of SD Negeri I Lundong as many as 20 students. Data collection techniques were observation and tests. The results of the research show that pretest results of writing skill is 67,70 with the minimum learning completeness of $55 \%$. Following the treatment, the class average increasse become 71,10 with the minimum learning completeness of $60 \%$ in a cycle I, and the class average is 77,28 with the minimum learning completeness of $82,50 \%$ in cycle $\mathrm{II}$, and the class average is 84,60 with the minimum learning completeness of $90 \%$ in cycle III. Based on the research results, a conclusion is drawn that CIRC Model can improve the skills of writing on the students in grade V of SD Negeri 1 Lundong.
\end{abstract}

Keywords: CIRC, writting skills

\begin{abstract}
Abstrak
Penelitian ini dilatarbelakangi oleh proses dan hasil belajar muatan pelajaran Bahasa Indonesia pada peserta didik kelas $V$ yang masih rendah di SD Negeri 1 Lundong. Tujuan penelitian ini adalah untuk meningkatkan keterampilan menulis surat undangan pada peserta didik kelas $\mathrm{V}$ SD Negeri 1 Lundong melalui model pembelajaran CIRC. Bentuk penelitian ini adalah penelitian tindakan kelas (PTK) yang dilaksanakan dalam tiga siklus. Tiap siklus terdiri dari empat tahap, yaitu perencanaan, pelaksanaan, observasi, dan refleksi. Subjek penelitian adalah peserta didik kelas $\mathrm{V}$ yang berjumlah 20 peserta didik. Teknik pengumpulan data yang digunakan adalah observasi dan tes. Hasil penelitian menunjukkan bahwa hasil pretest tentang keterampilan menulis surat undangan adalah 67,70 dengan persentase ketuntasan peserta didik kelas sebesar $55 \%$. Pada siklus I, nilai rata-rata kelas meningkat menjadi 71,10 dengan persentase ketuntasan kelas sebesar $60 \%$. Pada siklus II, nilai rata-rata kelas meningkat menjadi 77,28 dengan persentase ketuntasan kelas sebesar $82,50 \%$. Pada siklus III, nilai rata-rata kelas meningkat menjadi 84,60 dengan persentase ketuntasan kelas sebesar $90 \%$. Simpulan penelitian ini adalah penerapan model pembelajaran CIRC dapat meningkatkan keterampilan menulis surat undangan pada peserta didik kelas V SD Negeri 1 Lundong.
\end{abstract}

Kata kunci: CIRC, keterampilan menulis 


\section{PENDAHULUAN}

Pembelajaran kurikulum 2013 mengedepankan keterampilan-keterampilan yang dibutuhkan dalam kehidupan abad 21. Keterampilan abad 21 antara lain yaitu keterampilan yang mencerminkan kompetensi $4 \mathrm{C}$ dalam pelaksanaan pembelajaran. Kompetensi 4C yaitu critical thinking, creatif thinking, collaborative, dan comunication (Atalay \& Belet, 2019). Jadi dalam pembelajaran, peserta didik harus dapat menguasai kemampuan untuk berpikir kritis, berpikir kreatif, mampu berkolaborasi, dan juga dapat mengomunikasikan hasil belajarnya. Kompetensi 4C tersebut hendaknya diterapkan pada setiap mata pelajaran dalam pembelajaran tidak terkecuali pada pembelajaran Bahasa Indonesia.

Pada mata pelajaran Bahasa Indonesia, standar kompetensi berisi kualifikasi kemampuan minimal peserta didik yang menggambarkan penguasaan pengetahuan, keterampilan berbahasa, dan sikap positif terhadap bahasa dan sastra Indonesia. Menurut Santosa, dkk. (2013) pembelajaran Bahasa Indonesia dibagi menjadi empat keterampilan yaitu membaca, mendengarkan, menyimak, dan menulis. Keterampilan menulis merupakan salah satu keterampilan yang harus dikuasai peserta didik. Menulis merupakan kemampuan seseorang dalam mengemukakan gagasan, perasaan, dan pemikiran kepada orang lain dengan media tulisan (Nurjamal, 2014) Manfaat menulis menurut Dalman (2016) adalah mengembangkan kecerdasan, mengembangkan daya inisiatif dan kreativitas, menumbuhkan keberanian, serta mendorong kemauan kemampuan mengumpulkan informasi. Keterampilan menulis dapat mengekspresikan diri dan juga melatih kreativitas peserta didik dalam menggunakan bahasa yang tepat, karena dari tulisan dapat tercermin seperti apa pikirannya (Arum, 2017). Penggunaan model pembelajaran yang tepat akan membantu peserta didik mengusai keterampilan menulis tersebut. Salah satu model pembelajaran yang mendukung keterampilan menulis adalah model pembelajaran Cooperative Integrated Reading and Composition (CIRC).

Salah satu contoh keterampilan menulis yang harus dimiliki peserta didik adalah keterampilan menulis surat undangan. Irene (2017) mengungkapkan bahwa surat undangan merupakan surat yang berisi pemberitahuan dan permintaan kesediaan seseorang untuk menghadiri suatu acara. Surat undangan menggunakan kalimat yang efektif, singkat, padat, dan jelas. Tujuannya agar pembaca memahami isi surat yang diterima. Surat undangan dibagi menjadi dua jenis yaitu surat undangna resmi dan surat undangan tidak resmi. Berdasarkan pendapat tersebut, dapat diketahui bahwa menulis surat undangan memerlukan keterampilan menulis yang baik agar tujuan dari penulisan surat undangan dapat tercapai.

Berdasarkan hasil observasi guru kelas V SD Negeri 1 Lundong, terdapat beberapa masalah pada muatan pelajaran Bahasa Indonesia khususnya keterampilan menulis surat undangan yaitu: (a) masih banyak peserta didik yang sulit membedakan jenis surat undangan, (b) peserta didik belum memahami bagian-bagian surat undangan, (c) penggunaan ejaan masih belum sesuai, (d) tata letak penulisan surat undangan belum sesuai, (e) Penulisan huruf dalam surat undangan belum sesuai.

Selain melakukan observasi kepada guru kelas $\mathrm{V}$, peneliti juga menganalisis hasil belajar peserta didik khususnya pada keterampilan menulis surat undangan. Hasil analisis mengindikasikan bahwaketerampilan menulis surat undangan peserta didik kelas $\mathrm{V}$ masih rendah.

Berdasarkan uraian masalah di atas, dapat disimpulkan bahwa kemampuan menulis surat undangan peserta didik kelas $\mathrm{V}$ di SD Negeri 1 Lundong masih rendah. Rendahnya kemampuan menulis peserta didik hendaknya diperbaiki dengan model pembelajaran yang inovatif dan sesuai dengan karakteristik peserta didik. Salah satu model pembelajaran yang inovatif yaitu model pembelajaran Cooperative Integrated Reading and Composition (CIRC). Slavin (2005) juga menyebutkan pengertian Cooperative Integrated Reading and Composition $(C I R C)$, yaitu sebuah program yang komprehensif untuk mengajari pelajaran membaca, menulis, dan seni berbahasa pada kelas yang lebih tinggi di sekolah dasar dan pelaksanaan CIRC lebih menekankan pada pembelajaran Bahasa Indonesia, terutama menulis pada anakanak sekolah dasar. Selaras dengan pendapat tersebut, Shoimin (2014) model pembelajaran CIRC merupakan model pembelajaran yang khusus mata pelajaran bahasa dalam rangka membaca dan menemukan ide pokok, pokok pikiran, atau tema sebuah wacana. Berdasarkan kedua pendapat tersebut, dapat disimpulkan bahwa model pembelajaran CIRC adalah program yang komprehensif untuk mengajari pelajaran membaca, menulis, dan seni berbahasa pada kelas yang lebih tinggi di sekolah dasar dan pelaksanaan CIRC lebih menekankan pada 
pembelajaran Bahasa Indonesia, terutama menulis, membaca dan menemukan ide pokok, pokok pikiran, atau tema sebuah wacana.

Menurut Shoimin (2014) menyebutkan bahwa langkah-langkah penerapan Model Pembelajaran CIRC dibagi atas beberapa fase, yakni sebagai berikut: (1) Fase orientasi, (2) Fase organisasi, (3) Fase pengenalan konsep, (4) Fase Publikasi, (5) Fase atau tahap penguatan dan refleksi. Pada penelitian ini langkah-langkah penerapan model pembelajaran CIRC meliputi, enam langkah yaitu: (1) Fase Orientasi, (2) Fase Organisasi, membentuk kelompok yang terdiri atas 4-5 peserta didik secara heterogen; (3) Fase Pengenalan Konsep, guru memberikan kepadapeserta didik wacana/kliping yang sesuai dengan topik pembelajaran; (4) Fase Eksplorasi dan Aplikasi, peserta didik melakukandiskusi, dan bekerja sama menemukan kalimat utama, ide pokok, dan memberikan tanggapan atas wacana/kliping yang diberikan guru dalambentuk bahasa tulis; (5) Fase Publikasi, perwakilan kelompok/secara bergantian peserta didikmembacakan/ mempresentasikan hasil kerjasamanya bersama kelompok masing-masing, kemudian guru melakukan penguatan; (6) Fase Refleksi dan Penguatan.

Menurut penelitian yang dilakukan Rakhmawati (2015) tentang penggunaan model pembelajaran CIRC menunjukkan adanya peningkatan keterampilan menulis. Hasil penelitian Purbandari (2016) menunjukkan hasil yang sama yaitu terdapat peningkatan pada proses keterampilan menulis peserta didik. Jadi, berdasarkan hasil penelitian tersebut dapat disimpulkan bahwa model pembelajaran CIRC dapat meningkatkan keterampilan menulis peserta didik sekolah dasar.

Berdasarkan uraian di atas, rumusan masalah dalam penelitian ini yaitu apakah penerapan model pembelajaran CIRC dapat meningkatkan keterampilan menulis surat undangan pada peserta didik kelas V SDN 1 Lundong

Penelitian ini bertujuan untuk meningkatkan keterampilan menulis surat undangan pada peserta didik kelas V SDN 1 Lundong melalui penerapan model pembelajaran CIRC.

\section{METODE}

Penelitian Tindakan Kelas ini dilaksanakan di kelas V SD Negeri 1 Lundong, Kecamatan Kutowinangun, Kabupaten Kebumen. Subjek penelitian ini 20 peserta didik yang terdiri dari 11 anak laki-laki dan 9 anak perempuan. Alat pengumpulan data yaitu instrumen tes berupa soal evaluasi, dan instrumen nontes berupa lembar observasi. Pelaksana tindakan ialah guru kelas. Observer dalam penelitian ini yaitu dua orang teman sejawat. Data dalam penelitian ini data kuantitatif yang berupa berupa hasil observasi pembelajaran bahasa Indonesia pada peserta didik kelas $\mathrm{V}$, nilai hasil belajar, data kualitatif berupa informasi pembelajaran dengan model CIRC. Penelitian ini menggunakan teknik triangulasi sumber yang berasal dari peserta didik kelas $\mathrm{V}$, teman sejawat, dan dokumen. Triangulasi teknik dengan observasi dan tes.Penelitian ini dilaksanakan selama tiga siklus. Setiap siklus terdiri dari 2 pertemuan dengan 4 tahapan sesuai pendapat Arikunto (2010) yaitu (1) perencanaan, (2) pelaksanaan, (3) pengamatan, dan (4) refleksi.

\section{HASIL DAN PEMBAHASAN}

Penelitian terhadap keterampilan menulis surat undangan pada peserta didik kelas $V$ SD Negeri 1 Lundong dilaksanakan dengan menerapkan model CIRC yang sesuai dengan langkah-langkah penerapannya. Penelitian ini dilaksanakan dalam tiga siklus. Setiap sikus terdiri dari dua pertemuan. Data hasil observasi dari observer terkait penerapan model CIRC pada pembelajaran bahasa Indonesia oleh guru pada siklus I, II, dan III sebagai berikut.

Tabel 1. Perbandingan Penerapan Model CIRC terhadap Guru dan Peserta didik

\begin{tabular}{lccc}
\hline \multirow{2}{*}{ Sumber Data } & \multicolumn{3}{c}{ Persentase (\%) } \\
\cline { 2 - 4 } & Siklus I & Siklus II & Siklus III \\
\hline Guru & 71,88 & 88,54 & 94,79 \\
\hline Peserta Didik & 69,79 & 83,33 & 88,54 \\
\hline
\end{tabular}

Berdasarkan tabel 1, dapat diketahui bahwa penerapan model CIRC terhadap guru pada siklus I mencapai rata-rata 70,83\% kemudian meningkat pada siklus II menjadi $88,54 \%$ dan 
meningkat lagi pada siklus III menjadi 94,79\%. Hasil observasi penerapan model CIRC terhadap peserta didik pada siklus I mencapai rata-rata $69,79 \%$ kemudian meningkat pada siklus II menjadi $83,33 \%$ dan pada siklus III meningkat lagi menjadi $88,54 \%$. Perbandingan hasil observasi penerapan model pembelajaran CIRC terhadap guru dan peserta didik siklus I, II, dan III juga dapat dilihat dalam gambar berikut ini.

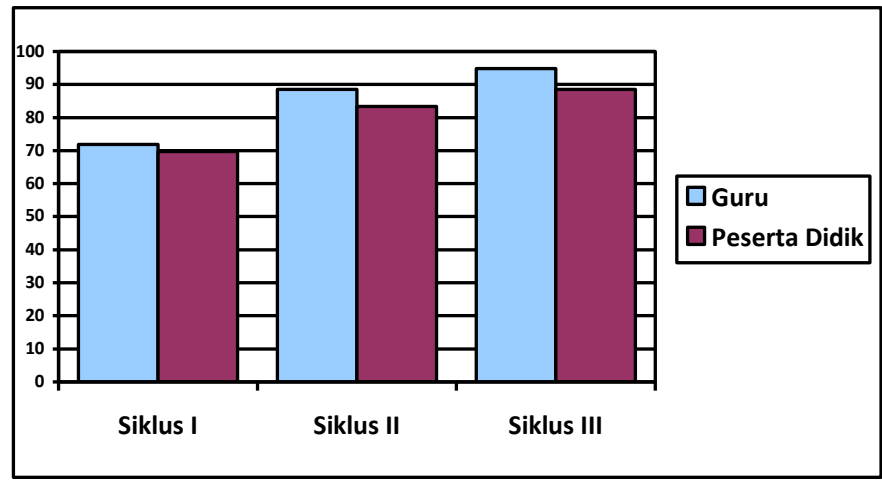

Gambar 1. Perbandingan Hasil Observasi Penerapan Model CIRC terhadap Guru dan Peserta didik Siklus I, II, dan III

Berdasarkan gambar di atas, dapat disimpulkan bahwa penerapan model CIRC terhadap guru dan peserta didik pada setiap siklus meningkat. Perbandingan hasil keterampilan menulis surat undangan antar siklus disajikan dalam tabel 3 berikut:

Tabel 3. Perbandingan Hasil Keterampilan Menulis Surat Undangan Siklus I, II dan III.

\begin{tabular}{lcccc}
\hline & \multicolumn{4}{c}{ Tindakan } \\
\hline & Pratindakan & Siklus I & Siklus II & Siklus III \\
\hline Rata-rata & 67,70 & 71,10 & 77,28 & 84,60 \\
\hline Persentase (\%) & 55 & 70 & 82,50 & 90 \\
\hline
\end{tabular}

Berdasarkan tabel 3, menunjukkan bahwa hasil pretest tentang keterampilan menulis surat undangan adalah 67,70 dengan persentase ketuntasan peserta didik kelas sebesar $55 \%$. Pada siklus I, nilai rata-rata kelas meningkat menjadi 71,10 dengan persentase ketuntasan kelas sebesar $70 \%$. Pada siklus II, nilai rata-rata kelas meningkat menjadi 77,28 dengan persentase ketuntasan kelas sebesar $82,50 \%$. Pada siklus III, nilai rata-rata kelas meningkat menjadi 84,60 dengan persentase ketuntasan kelas sebesar $90 \%$. Perbandingan Hasil Keterampilan Menulis Surat Undangan Siklus I, II, dan III juga dapat dilihat dari gambar berikut ini.

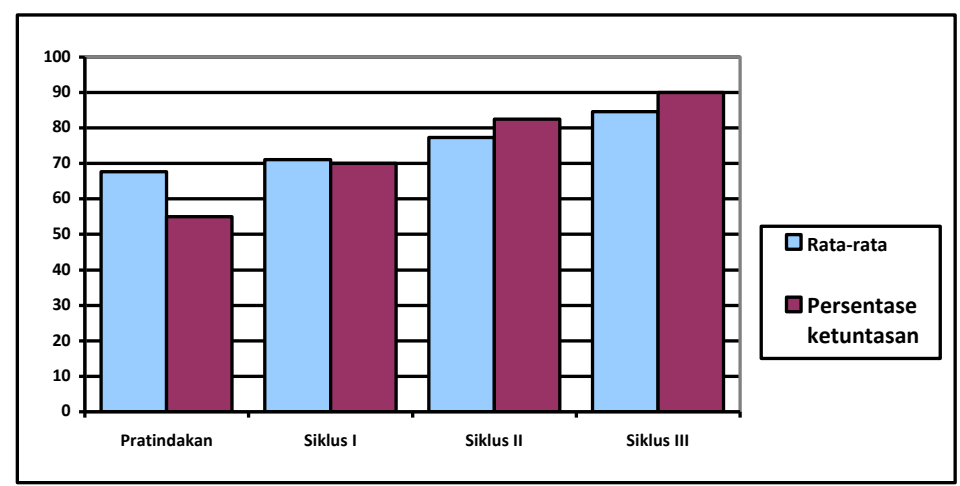

Gambar 2. Perbandingan Hasil Keterampilan Menulis Surat Undangan Siklus I, II, dan III 
Berdasarkan gambar di atas, dapat disimpulkan bahwa rata-rata dan ketuntasan nilai peserta didik mengalami peningkatan setiap siklusnya. Berdasarkan analisis peneliti mengenai penerapan model pembelajaran CIRC yang dilaksanakan sesuai dengan langkah-langkah pembelajaran selama tiga siklus dapat diketahui bahwa keterampilan peserta didik dalam menulis surat undangan meningkat. Hal ini dibuktikan dengan ketuntasan hasil evaluasi keterampilan menulis surat undangan yang meningkat pada setiap siklusnya. Pada siklus I ketuntasan hasil evaluasi keterampilan menulis surat undangan peserta didik yaitu sebesar $70 \%$, kemudian pada siklus II meningkat menjadi $82,50 \%$, meningkat lagi pada siklus III sebesar $90 \%$. Data tersebut menunjukkan bahwa penerapan model pembelajaran CIRC dapat meningkatkan keterampilan menulis surat undangan peserta didik kelas V SD Negeri 1 Lundong tahun ajaran 2020/2021. Hal ini relevan dengan penelitian yang dilakukan Purbandari (2016) yang mengungkapkan bahwa penerapan model CIRC dapat meningkatkan keterampilan menulis puisi pada siswa Kelas V SDN Candiwulan Tahun Ajaran 2015/2016. Begitu juga dengan pendapat Rakhmawati (2015) yang menyatakan bahwa penerapan Model CIRC (Cooperative Integrated Reading And Composition) dapat Meningkatkan Keterampilan Menulis Narasi Siswa Kelas IV SDN 1 Logandu Kebumen Tahun Ajaran 2014/2015.

\section{SIMPULAN}

Berdasarkan hasil penelitian diperoleh simpulan bahwa penerapan model pembelajaran CIRC dapat meningkatkan keterampilan menulis surat undangan peserta didik kelas V SD Negeri 1 Lundong. Hal ini dibuktikan dengan adanya peningkatan ketuntasan beajar peserta didik yang ditinjau dari hasil evaluasi keterampilan menulis surat undangan pada setiap siklusnya. Pada siklus I ketuntasan hasil evaluasi keterampilan menulis surat undangan peserta didik yaitu sebesar $70 \%$, kemudian meningkat pada siklus II menjadi $82,50 \%$, meningkat lagi pada siklus III sebesar $90 \%$.

\section{DAFTAR PUSTAKA}

Arikunto, S. (2010). Prosedur Penelitian Suatu Pendekatan Praktik. Jakarta: Rineka Cipta.

Arum, T.L., Mudzanatun, \& Damayanti, A.T. (2017). Keefektifan Media Audio Visual sebagai Kreativitas Guru Sekolah Dasar dalam Menumbuhkan Keterampilan Menulis Puisi Siswa. Universitas PGRI Semarang. Journal Scholaria, 7(3), 214-225.

Atalay, N., \& Belet, S.D. (2019). Slowmation Application in Development of Learning and Innovation Skills of Students in Science Course. 11 (5), 507-518. https://doi.org/10.26822/iejee.2019553347.

Dalman. (2016). Keterampilan Menulis. Jakarta: Rajawali Pers.

Indradi. (2018). Buku Pendamping Tematik Terpadu Bahasa Indonesia. Jakarta: Erlangga.

Irene, MJA, dkk. (2017). Buku Penilaian BUPENA untuk SD/MI Kelas V. Jakarta: Erlangga.

Nurjamal, D., Sumirat, W., \& Darwis, R. (2014). Terampil Berbahasa. Bandung: Alfabeta.

Purbandari, S. (2016). Penerapan Model CIRC dengan Media Gambar Peristiwa dalam Peningkatan Keterampilan Menulis Puisi pada Siswa Kelas V SDN Candiwulan Tahun Ajaran 2015/2016. Universitas Sebelas Maret. Kalam Cendekia. 4(3.1), 304-309

Rakhmawati. (2015). Penerapan Model CIRC (Cooperative Integrated Reading And Composition) untuk Meningkatkan Keterampilan Menulis Narasi Siswa Kelas IV SDN 1 Logandu Kebumen Tahun Ajaran 2014/2015. Skripsi Tidak Dipublikasikan. Universitas Sebelas Maret.

Santosa, P., dkk. (2013). Materi dan Pembelajaran Bahasa Indonesia SD. Jakarta: Universitas Terbuka.

Shoimin, A. (2014). 68 Model Pembelajaran Inovatif dalam Kurikulum 2013. Yogyakarta: ArRuzz Media.

Slavin, R. (2005). Cooperative Learning-Teori, Riset dan Praktik. Bandung: Nusa Media. 